https://doi.org/10.17816/MAJ191S151-54

\title{
CHANGES OF INTESTINAL MICROBIOME IN MULTIPLE SCLEROSIS ARE ASSOCIATED WITH IMMUNE SHIFT AND PSYCHOEMOTIONAL DISORDERS
}

\author{
I.N. Abdurasulova ${ }^{1}$, A.V. Matsulevich ${ }^{1}$, E.A. Tarasova ${ }^{1}$, I.V. Kudryavtsev ${ }^{1}$, I.G. Nikiforova ${ }^{2}$, \\ M.K. Serebryakova ${ }^{1}$, M.I. Miroshnichenko ${ }^{1}$, E.V. Ivashkova ${ }^{2}$, A.E. Tatarinov ${ }^{1}$, A.G. Ilves ${ }^{2}$, \\ E.I. Ermolenko ${ }^{1}$, G.N. Bisaga ${ }^{3}$, I.D. Stolyarov ${ }^{2}$, V.M. Klimenko ${ }^{1}$ \\ ${ }^{1}$ Institute of experimental medicine, Saint Petersburg, Russia; \\ ${ }^{2}$ N.P. Bechtereva Institute of the Human Brain of the RAS, Saint Petersburg, Russia; \\ ${ }^{3}$ Almazov National Medical Research Center, Saint Petersburg, Russia
}

\section{ИЗМЕНЕНИЯ МИКРОБИОМА КИШЕЧНИКА ПРИ РАССЕЯННОМ СКЛЕРОЗЕ СВЯЗАНЫ С ИММУННЫМИ ИЗМЕНЕНИЯМИИ ПСИХОЭМОЦИОНАЛЬНЫМИ НАРУШЕНИЯМИ}

И.Н. Абдурасулова ${ }^{1}$ А. В. Мацулевич ${ }^{1}$ Е А Тарасова ${ }^{1}$ И. В. Кудрявцев ${ }^{1}$ И. Г Никиророва ${ }^{2}$ М.К. Серебрякова ${ }^{1}$, М.И. Мирошниченко ${ }^{1}$, Е.В.Ивашкова ${ }^{2}$, А.Е. Татаринов $^{1}$, А.Г. Ильвес ${ }^{2}$, Е.И. Ермоленко ${ }^{1}$, Г.Н. Бисага ${ }^{3}$, И.Д. Столяров ${ }^{2}$, В.М. Клименко

${ }^{1}$ ФГБНУ «Институт экспериментальной медицины», Санкт-Петербург;

${ }^{2}$ ФГБУН «Институт мозга им. Н.П. Бехтеревой» РАН, Санкт-Петербург;

${ }^{3}$ ФГБУ «Национальный медицинский исследовательский центр им. В.А. Алмазова», Санкт-Петербург

Recently, the role of the intestinal microbiota in MS has been actively investigated in connection with its influence the development and activity of immune and nervous systems. It is assumed that immune dysfunction, as well as disorders of the gastrointestinal tract and psycho-emotional functions in patients with MS, may be associated with intestinal microbiocenosis dysbiosis. The aim of the study was to assess changes in the intestinal microbiome in MS patients and to analyze the associations of the bacterial level with various subsets of Th cells in the blood and psycho-emotional disorders. 126 MS patients with disease duration of $12.2 \pm 0.9$ years and 69 healthy individuals were examined. Intestinal microbiome was determined by the Illumina/Solexa sequencing method. The quantitative content of microbial species was determined by the method of cultivation and real time PCR with specific primers, subsets of Th cells - by flow cytometry. Patients were assessed for anxiety, depression, and asthenia. It was shown that the intestinal microbiome of MS patients was significantly changed compared with healthy individuals: the proportion of Bacteroides, especially of the Prevotellaceae family, was reduced, the proportion of Firmicutes (Bacilli and Clostridia) and Actinobacteria was increased, and the symbiotic species in Enterobacteriaceae family were replaced by opportunistic species. A positive correlation between the level of Bifibobacteria spp. with disease severity and blood levels of DP Th17 CM cells. Enterobacter spp. level correlated with the level of "classical" or Th17/22 CM and DP Th17 EM. Bifidobacteria spp. the level was also associated with the level of depression in patients, the level of Escherichia coli and Prevotella spp. - with anxiety, and the level of atypical E. coli and Sutterella spp. - with asthenia. The data obtained suggest that immune and psycho-emotional disorders in patients with MS can be corrected by normalizing intestinal microbiocenosis.

Keywords: multiple sclerosis; intestinal microbiome; anxiety; depression; Th17 subtypes.

В последние годы активно исследуется роль кишечной микробиоты при РС в связи с ее влиянием на формирование и деятельность иммунной и нервной систем. Предполагается, что иммунная дисфункция, а также расстройства функций ЖКТ и психоэмоциональной сферы у пациентов с РС могут быть связаны с дисбиозом кишечного микробиоценоза. Цель исследования - оценить изменения микробиома у пациентов с РС и проанализировать связь уровня отдельных видов бактерий с различными субпопуляциями Тh в крови и психоэмоциональными нарушениями. Обследовано 126 пациентов с РС с длительностью заболевания 12,2 \pm 0,9 лет и 69 здоровых лиц. Кишечный микробиом определяли методом секвенирования Illumina/Solexa. Количественное содержание видов микроорганизмов определяли методом культивирования и ПЦР в режиме реального времени со специфическими праймерами, субпопуляции Тh клеток - методом проточной цитометрии. У пациентов оценивали уровень тревожности, депрессии и астении. Показано, что кишечный микробиом пациентов с РС сушественно изменен по сравнению со здоровыми лицами: уменьшена доля Bacteroides, особенно семейства Prevotellaceae, увеличена доля Firmicutes (классов Bacilli и Clostridia) и Actinobacteria, а симбиотические представители семейства Enterobacteriaceae замещены условно-патогенными бактериями. Выявлена положительная корреляция между уровнем Bifibobacteria spp. с тяжестью заболевания и содержанием в крови субпопуляции DP Th17 CM клеток; наличием Enterobacter spp. - с уровнем «классических» Th17 (Th17/22) CM и DP Th17 EM. Увеличение популяции Bifidobacteria spp. также было связано с уровнем депрессии у пациентов, Escherichia coli и Prevotella spp. - с тревожностью, а атипичных 
E. coli и Sutterella spp. - с астенией. Полученные данные позволяют предположить, что иммунные и психоэмоциональные нарушения у пациентов с РС могут корректироваться путем нормализации кишечного микробиоценоза.

Ключевые слова: рассеянный склероз; кишечный микробиом; тревожность; депрессия; субтипы Th17.

Introduction. Recently, the brain-gut-microbiome axis has become a major research area at the neuroscience and neuroimmunology. The study of intestinal microbes influence immunity, brain, and behavior will offer a more complete understanding of neuro-immune interactions and human psychology [1]. Multiple sclerosis (MS) is a disease in which immune system dysfunction and nervous system disruption are observed. Following, patients have psycho-emotional disorders and disturbances of the gastrointestinal tract $[2,3]$. Changes in the gut microbiome in MS are shown [4, 5], however, it has not been investigated as it is associated with immune and psycho-emotional disorders. The aim of the study was to assess the changes in the intestinal microbiome in MS patients and to analyze the associations of bacterial level with various peripheral blood Th cell subsets as well as with psycho-emotional disorders.

Material and methods. The study involved 126 patients ( 82 female; 44 male) with duration of MS $12.2 \pm 0.9$ years. The control group (CG) consisted of 69 healthy volunteers. Characteristics of the patients are shown in the table. Metagenomic analysis of gut microbiome (16rRNA) was determined using the Illumina/Solexa sequencing me- thod. The quantitative content of microorganisms was determined by the method of cultivation and qPCR, as described previously [3]. Th phenotypes in peripheral blood were determined by flow cytometry [6]. Psycho-emotional state was assessed as previously described [2], additionally used the hospital anxiety and depression scale (HADS).

Results and discussion. In the gut microbiome of MS patients, the proportion of Bacteroides was decreased compared to CG ( $28 \%$ vs. $50 \% ; p=0,023)$, especially Prevotellaceae (3\% vs. $21 \%$ ) and the shares of Firmicutes (57\% vs. 36\% in CG) and Actinobacteria (4\% vs. $1 \%$ in CG) were increased. The proportions of class Bacilli (Streptococcaceae) and Clostridia representatines (Ruminococcaceaea and Christensenellaceae) included in the phylum Firmicutes were increased in MS patients. This data is consistent with the one of the other authors [4, 5].

Archaea (Methanobacteriaceae) were detected only in MS, especially in patients with early disease onset and with a higher disease severity (EDSS > 3.5). In Enterobacteriaceae (phylum Proteobacteria) symbiotic species were replaced by opportunistic species, that correlated with the severity of the disease. The increasing level of Bifidobacteria spp. and Enterococcus spp. has a

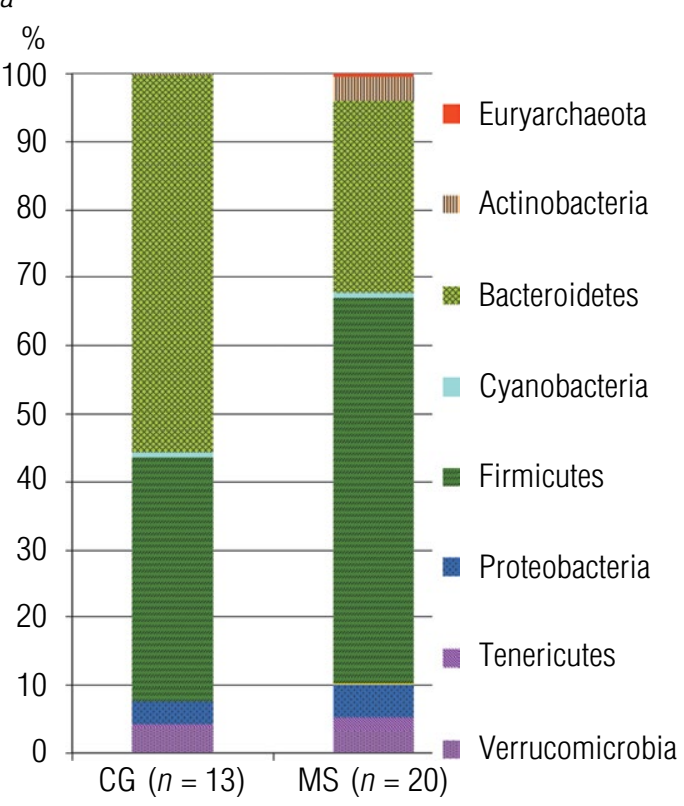

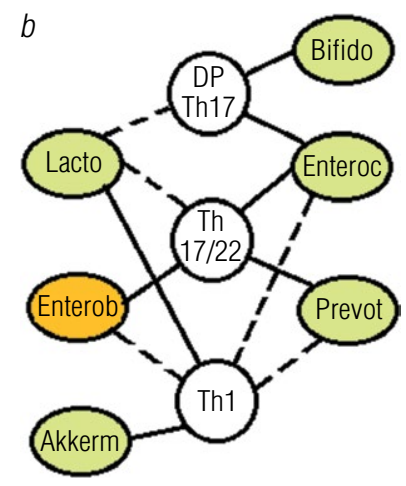

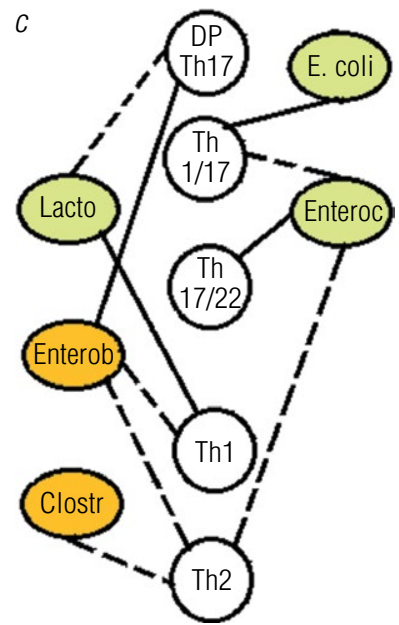

Fig. 1. Changes in microbiome $(a)$ and correlations bacterial level with subpopulations Th central memory $(b)$ and effector memory $(c)$ in MS patients. $a$ : CG - control group; MS - multiple sclerosis group; $b-c$ : Th1, Th2, Th1/17, Th17/22, DP Th17 - the different subpopulations of T helper cells; Lacto - Lactobacillus spp., Bifido - Bifidobacterium spp., Enteroc - Enterococcus spp., E. coli - Escherichia coli, Prevot - Prevotella spp., Akkerm - Akkermansia muciniphila, Enterob - Enterobacter spp., Clostr - Clostridium spp. Green colored - bacteria with suggested positive role in MS; Orange colored - bacteria with a negative role in MS; solid line - positive correlation; dotted line negative correlation 
Characteristics of the studied group

\begin{tabular}{|c|c|c|c|c|c|c|c|c|}
\hline \multirow{2}{*}{ Group } & \multicolumn{3}{|c|}{ Patients characteristics } & \multicolumn{5}{c|}{ Psycho-emotional characteristics } \\
\cline { 2 - 9 } & $n$ & age & EDSS & AS & RA & DL & HADS (A) & HADS (D) \\
\hline CG & 69 & $41.7 \pm 1.1$ & - & $\begin{array}{c}38.5 \\
(32.0-46.5)\end{array}$ & $\begin{array}{c}32.0 \\
(24.5-44.0)\end{array}$ & $\begin{array}{c}30.0 \\
(24.0-38.0)\end{array}$ & $\begin{array}{c}3.0 \\
(1.0-6.0)\end{array}$ & $\begin{array}{c}2.0 \\
(0.0-4.0)\end{array}$ \\
\hline MS & 126 & $39.4 \pm 1.0$ & $3.2 \pm 0.2$ & $\begin{array}{c}50.5 \\
(35.0-78.0)^{* *}\end{array}$ & $\begin{array}{c}42.0 \\
(27.0-58.0)^{* *}\end{array}$ & $\begin{array}{c}38.0 \\
(25.0-53.0)^{* *}\end{array}$ & $\begin{array}{c}5.0 \\
(0.0-11.0)^{*}\end{array}$ & $\begin{array}{c}4.0 \\
(1.0-9.0)^{* *}\end{array}$ \\
\hline
\end{tabular}

Note. Data presented as mean \pm st. error (age, EDSS) and median with 10-90 percentile (psycho-emotional characteristics). AS - asthenia scale; RA - reactive anxiety; DL - depression level (Zung depression scale); HADS hospital anxiety (A) and depression (D) scale; CG - control group; MS - multiple sclerosis group.

also been noted in cases of more severity of MS.

The certain bacterial species was associated with the content of several Th subsets. The frequency of Th1 cells at different stages of differentiation positively correlated with the levels of Lactobacillus spp. and Akkermansia muciniphila and negatively - with Enterococcus spp., Prevotella spp., Enterobacter spp. The levels of Lactobacillus spp., Enterococcus spp. and Enterobacter spp. also correlated with the relative numbers of "classical" or Th17/Th22 and DP Th17 cells, however, these dependencies were opposite with Th1. Bifidobacterium spp. level also correlated with DP Th17 content too. These data suggest that the changes in the microbiome could influence immune cell subsets frequencies and these changes could result in the prevalence of pathogenic Th17 subtypes in MS patients.

In addition, psycho-emotional disorders were detected in patients with MS (Table 1). The increased level of reactive anxiety (RA) was observed in majority $(83.5 \%)$ of MS patients. Mild or moderate asthenia ( 50.5 vs. 38.5 for CG) was noted in $48 \%$ of MS patients (AS). Mild depression of situational genesis was detected in $17 \%$ of patients with MS (DL), and subclinical depression was di- agnosed in $21.7 \%$ (HADS). Psycho-emotional disorders in MS patients positively correlated with the disease severity and were not related to gender.

Analysis of the relationship of these disorders with changes in the intestinal microbiome showed that depression in patients positively correlated with the Bifidobacteria spp. level and negatively with A. muciniphila level, anxiety - with levels of Escherichia coli and Prevotella spp., and asthenia with levels of atypical E. coli and Sutterella spp. More pronounced changes in micriome and connection of the bacterial level with psycho-emotional disorders were observed in patients with a more severity of the disease.

Thus, the revealed changes in gut microbiome in MS and their connection with immune shift and psycho-emotional disorders demonstrate that the intestinal microbiota may be the target for influence in correcting immune and psycho-emotional disorders. Preliminary studies have shown that probiotics, in particular, Enterococcus faecium L-3, can be used for this $[2,3]$.

Acknowledgments. Center for collective use of scientific equipment of the Research Institute of Agricultural Microbiology (E.E. Andronov and A.G. Pinaev) for help in microbiom sequencing.

\section{References}

1. Cryan JF, Dinan TG. Mind-altering microorganisms: the impact of the gut microbiota on brain and behaviour. Nat. Rev. Neurosci. 2012;13(10):701-712.

2. Matsulevich AV, Abdurasulova IN, Tarasova EA, et al. Effect of course application of Enterococcus faecium L-3 on the psychoemotinal state of patients with multiple sclerosis. Med. Acad. Zh. 2017;17(3):38-46. (In Russ.).

3. Abdurasulova IN, Tarasova EA, Ermolenko EI, et al. Multiple sclerosis is associated with the altered quantitative and qualitative composition of intestinal microbiota. Med. Acad. Zh. 2015;15(3):55-67. (In Russ.).

4. Miyake S, Kim S, Suda W, et al. Dysbiosis in the gut microbiota of patients with multiple sclerosis, with a striking depletion of species belonging to Clostridia XIVa and IV clusters. PLoS One. 2015;10(9):e0137429.

5. Jangi S, Gandhi R, Cox LM, et al. Alterations of the human gut microbiome in multiple sclerosis. Nat Commun. 2016;7:12015.

6. Kudryavtsev IV, Ilves AG, Borisov AG, et al. CCR6-positive T-helper subsets from peripheral blood in multiple sclerosis. Cytokines and inflammation. 2016:15(2):166-172. (In Russ.).

7. Abdurasulova IN, Matsulevich AV, Tarasova EA, et al. Enterococcus faecium L3 and glatiramer acetate ameliorate of experimental allergic encephalomyelitis (EAE) in rats by affecting different populations of immune cells. Beneficial microbes. 2016;7(5):719-729. 